\title{
High-impact floods and flash floods in Mediterranean countries: the FLASH preliminary database
}

\author{
M. C. Llasat ${ }^{1}$, M. Llasat-Botija ${ }^{1}$, M. A. Prat ${ }^{1}$, F. Porcú ${ }^{2}$, C. Price ${ }^{3}$, A. Mugnai ${ }^{4}$, K. Lagouvardos ${ }^{5}$, V. Kotroni ${ }^{5}$, \\ D. Katsanos $^{5}$, S. Michaelides ${ }^{6}$, Y. Yair ${ }^{7}$, K. Savvidou ${ }^{6}$, and K. Nicolaides ${ }^{6}$ \\ ${ }^{1}$ Department of Astronomy and Meteorology, University of Barcelona, Barcelona, Spain \\ ${ }^{2}$ Department of Atmospheric Physics, University of Ferrara, Ferrara, Italy \\ ${ }^{3}$ Department of Geophysics and Planetary Science, Tel Aviv University, Tel Aviv, Israel \\ ${ }^{4}$ Institute of Atmospheric Sciences and Climate, National Research Council, Roma, Italy \\ ${ }^{5}$ Institute of Environmental Research and Sustainable Development, National Observatory of Athens, Athens, Greece \\ ${ }^{6}$ Meteorological Service, Nicosia, Cyprus \\ ${ }^{7}$ Department of Life and Natural Sciences, The Open University of Israel, Ra'Anana, Israel
}

Received: 6 April 2009 - Revised: 18 February 2010 - Accepted: 26 February 2010 - Published: 18 March 2010

\begin{abstract}
This paper contains a preliminary analysis of flood risk in Mediterranean countries, conducted within the framework of the FLASH European Project. All flood events recorded between 1990 and 2006 in the Mediterranean region have been included in the study. Results of previous international projects (STORM, SPHERE, AMPHORE, RINAMED and MEDEX), as well as information provided by FLASH Project partners and data included in scientific papers were the main source used in building this database. All the above information had been dispersed in various places, and an attempt was made here to create, for the first time, a verified and complete single database for the entire Mediterranean region. The work analyses the spatial and temporal distribution of flood events, as well as their social impact, with special attention to certain case studies that have been analysed in detail.
\end{abstract}

\section{Introduction}

Leaving aside droughts, floods are the most dangerous meteorological hazards affecting the Mediterranean countries, followed by windstorms and hail. This is due not only to high flooding frequency, but also to the vulnerability created by various human activities. Indeed, for Mediterranean

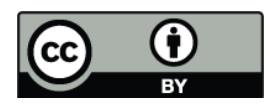

Correspondence to: M. C. Llasat (carmell@am.ub.es) regions such as eastern Spain, southern France, Italy and the west of the Balkan Peninsula, floods are frequent enough to be considered as a component of the local climate. These regions have widespread and intense economic activity and high population densities. This results in significant economic losses following flood events. Although floods affect the entire Mediterranean region, their frequency and impact is not homogeneous over the entire area. Their greater frequency and social impact in the north-western part, together with major preventive measures (emergency plans, environmental law, participation in international projects and so on), contrasts with the scant information on floods available in some southern and eastern countries. This fact points to a clear need for better coverage of such hazards in countries such as Spain, France and Italy.

Data compilation related to past flood events in the Mediterranean region has been the subject of several papers and projects. Some of these events are included in papers referring to Europe as a whole (Stanescu, 2000; Barredo, 2007). The paper by Barrera et al. (2006) deals with the evolution of flash floods in Barcelona County from the 14th to the 20th centuries, while in Llasat et al. (2005) the evolution of flood events for three main rivers of Catalonia (Spain) for the same period is analysed. In this region, a complete flood database implemented on a GIS that covers all the information available for the 20th century has been generated (Barnolas and Llasat, 2007). This database, called InunGAMA, includes information on affected areas and damage, generally provided by documentary resources,

Published by Copernicus Publications on behalf of the European Geosciences Union. 
and meteorological and hydrological information, following the example generated within the EU-funded SPHERE project (Casas et al., 2003). Naulet et al. (2001) also work with flood evolution in the Ardèche River (France) since the 19th century. Savvidou et al. (2008) analyse 43 flood cases in Cyprus for the period 1994-2006. The AVI (Area Vulnerable in Italia) archive stores historical information on landslides and floods in Italy as a whole for the 20th century (Guzzetti et al., 1994; Guzzetti and Tonelli, 2004), complemented with more detailed information for some regions such as Calabria (Petrucci and Versace, 2000) and Salento (Forte et al., 2005). The contributions made by Lastoria et al. (2006) and Petrucci and Polemio (2003) deal with the databases of hydrogeological events and their impact. A recent paper by Gaume et al. (2009) shows a preliminary catalogue for seven European regions that include the most extreme flash flood events between 1946 and 2007. The final data set includes 578 flood event records, some of them recorded in France, Italy, Spain, Greece and Romania.

Within the framework of the European Project FLASH (http://flash-eu.tau.ac.il/index.php: Observations, Analysis and Modelling of Lightning Activity in Thunderstorms, for use in Short-Term Forecasting of Flash Floods) the goal was set of using lightning data in order to achieve better skills in nowcasting and in forecasting the location, intensity and timing of heavy convective precipitation events. With the help of precipitation and radar data, cloud and meso-scale models, 20 case-studies of past (historical) flash flood events recorded in Israel, Cyprus, Italy, Greece and Spain were studied, with the aim of investigating the connection between intense precipitation and lightning activity. In parallel, the societal benefits of such advance forecasting were also investigated in the project, especially in relation to risk management and societal impacts. In order to meet this objective, a database of the main impacts produced by floods and flash floods in the Mediterranean region was constructed.

The structure of this paper is as follows: in Sect. 2, the sources of information are presented. Then, in Sect. 3 the methodology with the criteria considered is described. In Sect. 4 the temporal and spatial distribution of flood events in the Mediterranean region is presented, followed by Sect. 5 with the historical flash flood events and their societal impacts. Finally, the conclusions are presented, furnishing a summary of the results obtained, with some concluding remarks and pointers to future work.

\section{Sources of information}

Together with all the information extracted from the references included in the Introduction, data about floods and their impact has been supplied by four kinds of sources of information:

\subsection{International projects}

The following international projects and their data about floods were considered:

- MEDEX (Mediterranean Experiment on Cyclones that produce High Impact Weather in the Mediterranean);

- RINAMED (Elaboration et mise en place d'une stratégie commune entre acteurs locaux des régions de l'Arc Méditerranéen Occidental en matière d'information et de sensibilisation des populations face aux risques naturels, Interreg IIIB MEDOCC 2002-014.3-E-027);

- AMPHORE (Application des méthodologies de prévisions hydrométéorologiques orientées aux risques environnementaux, Interreg IIIB 2003-03-4.3-I-079);

- SPHERE (Systematic, Palaeoflood and Historical Data for the improvement of Flood Risk Estimation, European Union, VG1-CT-1999-00010);

- STORM (Flood hazard control by multisensors storm tracking in Mediterranean areas, CEE, EV5V-CT920167).

\subsection{Flood events and databases}

The following databases and information resources were considered in order to obtain more information concerning the flood cases identified from previous projects (damage, affected region etc).

- EM-DAT database: "The OFDA/CRED International Disaster Database - www.emdat.be - Université Catholique de Louvrain - Brussels - Belgium", with information since 1900 for all the countries of the world.

- European Severe Weather Database (ESWD): database on severe weather in Europe developed by European Severe Storms virtual Laboratory.

- Information from the companies Munich Reinsurance and Swiss Reinsurance, for the entire Mediterranean Region, and from the "Consorcio de Compensación de Seguros" for Spain.

\subsection{Newspapers}

All the news about floods contained in a Spanish press database for the period 1982-2007 have been considered (Llasat et al., 2009).

\subsection{Flood information obtained from reports}

Besides regular papers, some reports, like ESPON (20002006), Munich-Re (2004), CRED (2007) and Gard (Legrand et al., 2003), were also taken into account. 
Table 1. List of Mediterranean countries with those participating in the MEDEX project shown in red. The preliminary analysis of this paper was conducted on the basis of these latter countries.

\begin{tabular}{lll}
\hline Albania & Israel & Slovenia \\
\hline Algeria & Italy & Spain \\
\hline $\begin{array}{l}\text { Bosnia } \\
\text { Herzegovina }\end{array}$ & Lebanon & Syria \\
\hline Bulgaria & Libya & Tunisia \\
\hline Cyprus & Fyrom & Turkey \\
\hline Croatia & Morocco & \\
\hline Egypt & Protugal & \\
\hline France & Romania & \\
\hline Greece & Serbia & \\
& Montenegro & \\
\hline
\end{tabular}

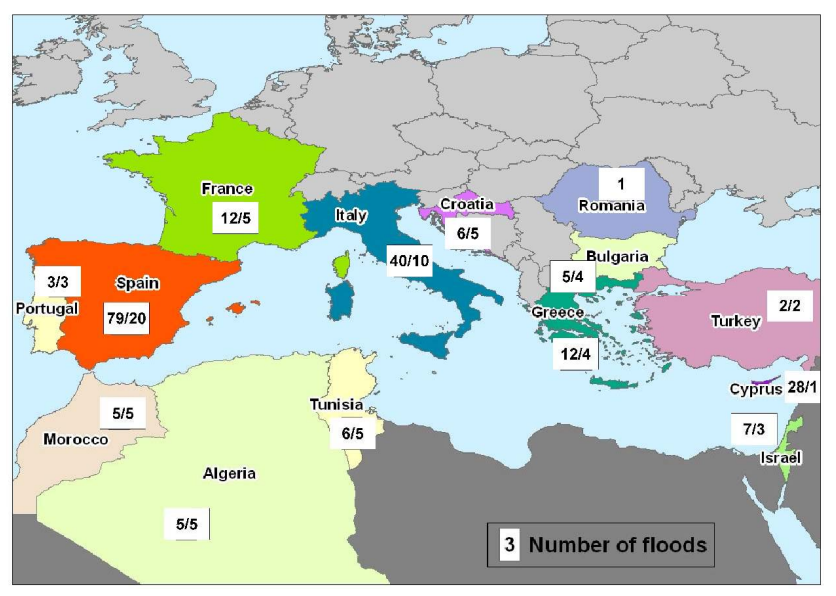

Fig. 1. Number of flood events from 1990 till 2006 for which information is available (left number indicator). Total number of flood events selected by the MEDEX database (1996-2004) (right number indicator).

\section{Methodology}

The list of selected cases of the MEDEX project (http:// medex.inm.uib.es) for the period 1995-2004 was used as the starting point. This table includes a total of 55 cases that resulted in strong winds, heavy rainfall or floods in one or more of the MEDEX countries shown in Table 1. Out of the 55 events, 54 were related to intense precipitation (daily accumulated precipitation of over $60 \mathrm{~mm}$ being required) that had a considerable social impact. This list has been updated with the information presented in the previous chapter and has been extended to the period 1990-2006. The information was verified according to the existing literature or weather
Number events I month MEDEX countries (1990-2006)

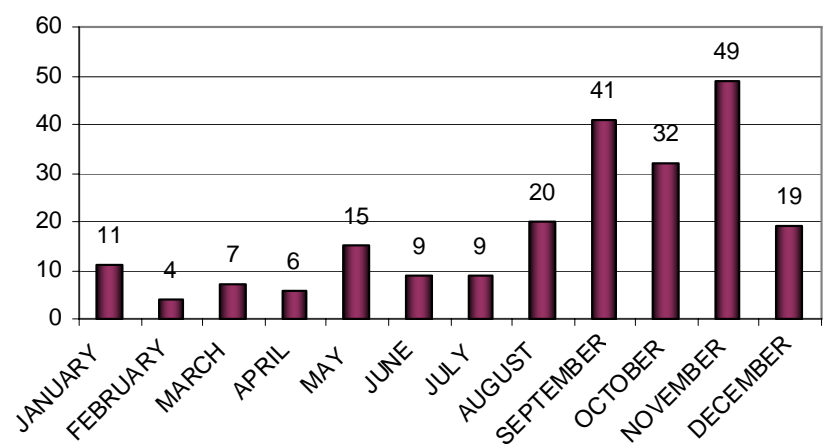

Fig. 2. Monthly distribution of all the flood cases recorded between 1990 and 2006.

maps, where necessary. For each case, meteorological and hydrological data as well as information concerning the social impact was obtained. The information about damage is very incomplete in some cases, so such data will be considered as a reference to minimal damage.

The interpretation of data analysis country-by-country must take into consideration: (a) the events that affected more than one country were counted once in each country; this means that when calculating the total of all countries, one event will be counted twice; (b) the temporal distribution was made on the basis of the initial date of the event.

\section{Spatial and temporal distribution}

A total of 185 flood events were recorded between 1990 and 2006. Due to the fact that one event can affect more than one country, and in that case will probably also have a major impact, it is interesting to obtain the total number of events by country, amounting to 222. Figure 1 shows the total number of events in each country. There are more events in Spain and Italy, probably due to higher flood frequency, but also to the availability of relevant information. The number of cases that affected Spain, Italy and France amounts to $59 \%$ of the total. Spain shows a maximum, with $36 \%$ of the total, but this difference in comparison with Italy and France is mainly due to data availability. Another cause of this great difference is that Fig. 1 includes all the flood events without imposing any criteria about damage or physical thresholds. The comparison with the number of events recorded in the MEDEX database shows how the flood frequency can change when a deeper analysis is undertaken, as in the cases of Spain (an average of 4.6 floods/year following the complete database, as compared with 2.4 floods/year following the MEDEX table), Italy and Cyprus.

Figure 2 shows the monthly distribution of flood events for the period 1990-2006. It is noted that the months of September, October and November have the largest number 
Number events / year MEDEX countries

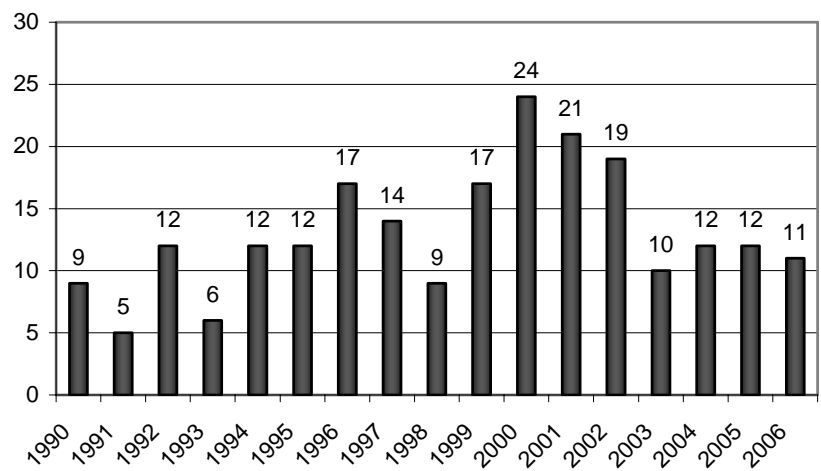

Fig. 3. Annual distribution of all the cases between 1990 and 2006.

of events, with $54.7 \%$ of the annual total, while the summer months (JJA) have $17.2 \%$ and winter $15.3 \%$. This result, which represents the whole Mediterranean area, is important for the analysis of climate-change impact on the floods in this region that corroborates the priority of the autumn season, as a clear difference from the other European countries. However, it is also important to note the $17.2 \%$ of floods are recorded in summer, and are usually flash floods that produce local, but significant damage.

Figure 3 shows the temporal evolution of flood events by country from 1990 to 2006 . There seems to be a slight increasing trend in the number of events over the years, though this trend is not statistically significant. Indeed, although the slope of the linear fit is 0.36 , the value of $r$ is 0.35 . This slightly increasing trend over the years could be due to a real increase in the number of flood events, to a vulnerability increase, or to the fact that more information is being provided. In fact, it has been shown that the impact of risks has increased in recent years (IPCC, 2007). A significant population growth in the countries bordering the Mediterranean has been observed: in 1985 these countries had a total population of 352 million people, and currently this number stands at about 450 million people. This major population pressure in the coastal regions, where short but torrential rivers experience frequent flash-floods, may be one cause of flood increase, as in the specific case of Catalonia (Llasat et al., 2008). Flash floods are considered here to be sudden floods arising in small basins as a consequence of heavy local rainfalls (for more information see Llasat, 2009, and Gaume et al., 2009).

Figure 3 also shows an important peak on the year 2000. Two catastrophic events were recorded in June and October that mainly affected Spain and the north of Italy (June), although France, Tunisia and Algeria also recorded important events. The second most important year was 2001, which recorded the most catastrophic wind storm and flood event in recent years, causing over 600 deaths in Algeria and four deaths and damage estimated at 37295218.38 in
Table 2. Damages and deaths caused by floods in the Mediterranean Region from 1990-2006.

\begin{tabular}{lll}
\hline Country & Deaths & Total Million Euro \\
\hline Albania & 19 & 15.8 \\
Algeria & 1206 & 198.9 \\
Bulgaria & 40 & 296.0 \\
Croatia & 3 & $\mathrm{~N} / \mathrm{I}^{*}$ \\
Egypt & 648 & 91.2 \\
France & 177 & 4042.5 \\
Greece & 41 & 820.1 \\
Israel & 32 & 33.7 \\
Italy & 466 & 19780.3 \\
Libya & $\mathrm{N} / \mathrm{I}^{*}$ & 27.0 \\
Fyrom & 2 & 226.3 \\
Morocco & 797 & 5.8 \\
Portugal & 21 & 8.3 \\
Romania & 383 & 1485.6 \\
Serbia Montenegro & 14 & $\mathrm{~N} / \mathrm{I}^{*}$ \\
Slovenia & $\mathrm{N} / \mathrm{I}^{*}$ & 3.2 \\
Spain & 170 & 757.7 \\
Syria & 6 & $\mathrm{~N} / \mathrm{I}^{*}$ \\
Tunisia & 49 & 155.4 \\
Turkey & 492 & 1188.2 \\
Total & 4,566 & $29,136.0$ \\
\hline
\end{tabular}

* N/I: No information available.

the Balearic Islands (Spain). Although in 2001, the Mediterranean did not experience such extended catastrophic floods as the central Europe, some important flash floods did occur in August 2002 in Spain, Algeria and Italy, while in France the "Gard event" (8-9 September 2002) caused damages of 1200 million and 23 casualties (Legrand et al., 2003). For this geographical part of the Mediterranean, 1996 was another important year. Indeed, 1996 was the wettest year in the last 20 years in Spain; a flood event was recorded in January (simultaneously with Morocco), unusual for this country, as well as a catastrophic flash flood in the south of Italy in October, simultaneously with a heavy rainfall event with some minor floods in Spain.

\section{Flood damage in Mediterranean countries}

Table 2 shows information about the damage produced by floods in all the countries of the Mediterranean region. This information is only approximate because it is not homogeneous for all the countries and periods. For the period 19902006, reported material damage exceeded 29136 million, Italy being the country with the greatest losses followed by France, Romania, Turkey and Spain. This amount decreases to 28772.5 million if only the 15 countries selected in Table 1 are considered. The highest number of casualties is found in Algeria, mainly as a consequence of the November 2001 
Table 3. Selected flood events considered by the FLASH project. The day of the month of each event of each month is shown (IS: Israel, I: Italy, C: Cyprus, G: Greece and S: Spain). The cases presented in this paper are shown in red.

\begin{tabular}{|c|c|c|c|c|c|c|c|c|c|c|c|}
\hline $\begin{array}{l}\text { Month } \\
\text { Year }\end{array}$ & $\mathrm{Feb}$ & Mar & Apr & May & Jun & Jul & Aug & Sep & Oct & Nov & Dec \\
\hline 2004 & & & & & & & & & $\begin{array}{l}29, \text { I } \\
29, \text { IS }\end{array}$ & $5-6, \mathrm{G}$ & \\
\hline 2005 & & & & & & & $2, S$ & & $\begin{array}{l}12-15, \mathrm{~S} \\
31, \mathrm{C}\end{array}$ & $\begin{array}{l}6, \mathrm{C} \\
17-9, \mathrm{C} \\
13-5, \mathrm{~S} \\
23-25, \mathrm{G}\end{array}$ & $17, \mathrm{C}$ \\
\hline 2006 & $3-6$, IS & & $1-2$, IS & & $15, \mathrm{I}$ & & $13, \mathrm{I}$ & $\begin{array}{l}8, \mathrm{I} \\
12-15, \mathrm{~S}, \mathrm{I}\end{array}$ & $\begin{array}{l}8-12, \mathrm{G} \\
28-30, \text { IS }\end{array}$ & & \\
\hline
\end{tabular}

Number events/month FLASH countries

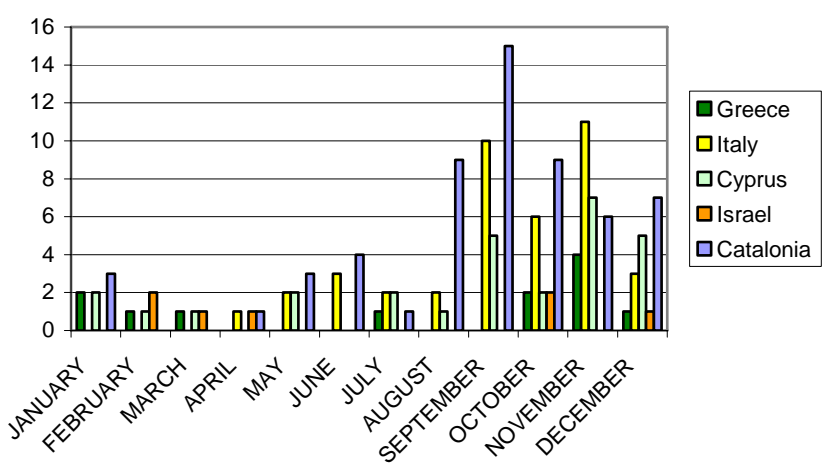

Fig. 4. Monthly distribution of floods in FLASH countries (19902006).

event, followed by Morocco, Egypt and Italy. The total number of casualties was over 4500 , concentrating especially in the African countries bordering the Mediterranean. This is a clear example of the difference between the most developed countries from the economic and human points of view.

\section{FLASH cases of study}

The FLASH project focuses on flash floods recorded in Cyprus, Greece, Italy, Israel and Spain. In the last country, 58 cases affected Catalonia (1990-2006), a region located in the north-eastern part that has experienced more than 200 floods in the 20th century (Barnolas and Llasat, 2007). For the same period, Cyprus has recorded 28 flood events, with the Nicosia region being the most severely affected. As an example, a major severe weather situation was recorded in the south of Cyprus on 22 January 2004, giving rise to violent thunderstorms, hail and intense precipitation as well as seven tornadoes. The area of Athens is the most affected region in Greece, a country that has experienced 12 floods (1990-2006). Floods in Greece are usually produced by heavy, but short rainfall events, and the role of deforestation and urbanisation is very important in their genesis. They are more destructive in the western part of Greece due to the climatic, geomorphic, geomorphologic, vegetation and human conditions. The most serious flood that occurred in the past 15 years was in October 1994, when a thunderstorm produced $68 \mathrm{~mm}$ in one hour in Athens (Lagouvardos et al., 1996) leading to material damage evaluated at 13 million for commercial and industrial properties and 1 million for residential properties. In Italy, where more than 40 flood events occurred during this period, the worst affected regions were Piemonte, Liguria, Lombardy and Calabria. As an example, the catastrophic floods of 26-28 September 1992 produced four casualties and one missing person in the south of France, and a few casualties in the urban area of the town of Genoa (Liguria, Italy), where more than US\$ 12 million were needed for urgent salvage work. Finally, Israel recorded seven flood events during the period 1990-2006, where the central region was the one worst affected. As an example, the 21-22 February 1997 flood event in Israel produced 11 casualties and major losses in agriculture. A deeper analysis of all the events recorded in this period shows that floods in these countries mainly affect urban areas, due to the conversion of water courses into streets, and that they are usually flash floods.

From these 145 flood events that have affected the regions involved in the FLASH project during the period 1990-2006, a sample of 20 flood cases was selected in the FLASH project for an in-depth analysis. Table 3 shows the place and date in each case. Besides them, another flood case recorded in Israel on December 2001 was also considered. Flood events are mainly concentrated in autumn, and only Israel and Cyprus have recorded heavy rainfall events in winter. Figure 4 corroborates this distribution. Events recorded in summer usually produce local flash floods that cause a lot of 

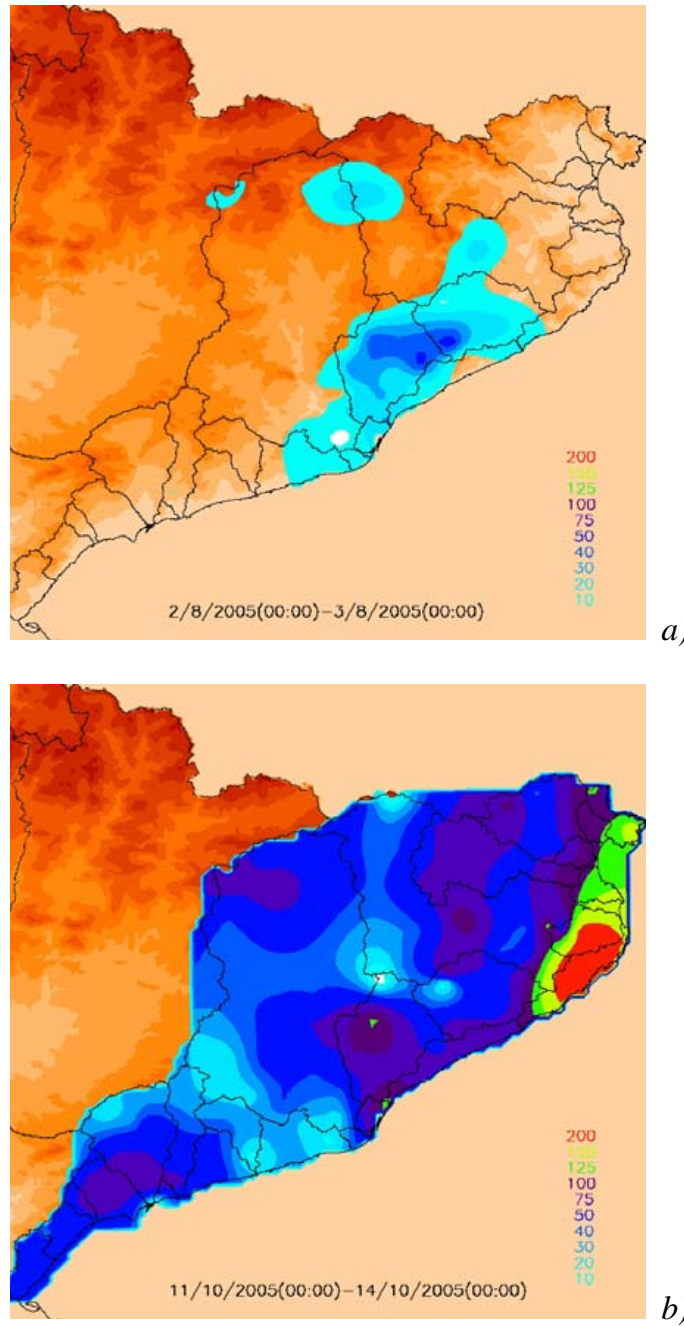

b)

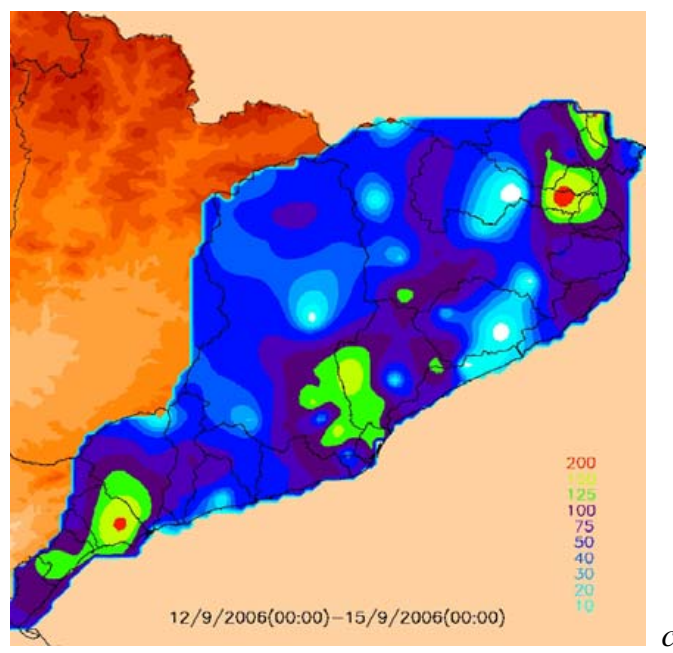

c)

Fig. 5. Total rainfall recorded in the Internal Basins of Catalonia, Spain, in the course of the events: (a) 2 August 2005; (b) 11-13 October 2005; (c) 12-14 September 2006. damage to cars. Some flood events are meteorologically related, like the one of September 2006 that affected Spain first and afterwards, Italy.

Of the 20 cases, some were selected as examples of different flood types with strong social impact, following the classification shown in Llasat et al. (2005) in relation to damages, and Llasat $(2001,2009)$ and Rigo and Llasat (2005) in relation to convective rainfall contribution. The first shows a short and local summer flash flood event. The second one is a typical autumn high-rainfall event in north-western Mediterranean countries that lasted between 24 and $72 \mathrm{~h}$ and gave rise to flash floods in a small region. The third type refers to an extended heavy rainfall event that affected more than one country, causing major losses. Some eastern Mediterranean cases are also presented: a spring flash flood event in Israel, and two autumn events in Greece and Cyprus.

\section{(a) 2 August 2005, Spain}

On 2 August 2005 some extraordinary flash floods affected the Besós, Tordera and Barcelona catchments, while hail was recorded in some parts of Catalonia. It was a strongly convective event, with a maximum of $56 \mathrm{~mm}$ in $1 \mathrm{~h}$ and $57.1 \mathrm{~mm}$ in $24 \mathrm{~h}$ (Fig. 5a). In some regions more than $80 \%$ of the precipitation was convective. One farmer died because he was swept away by the current while driving his tractor. Agricultural damage and breaches in roads, railway and electrical power also occurred. Strong winds, lightning and hail also caused damage.

\section{(b) 11-13 October 2005, Spain}

Between 11 and 13 October 2005 several catastrophic flash floods occurred along the coast of Catalonia due to a significant heavy rainfall event. Maximum rainfall reached accumulations of up to $250 \mathrm{~mm}$ in $24 \mathrm{~h}(134 \mathrm{~mm}$ within few hours and 5-min intensities close to $100 \mathrm{~mm} / \mathrm{h}$ ), and more than $340 \mathrm{~mm}$ in the entire episode were recorded in some places along the north Catalan coast (Fig. 5b). It was a moderate convective event. Some ephemeral or small rivers (basin areas between $90 \mathrm{~km}^{2}$ and $340 \mathrm{~km}^{2}$ ) overflowed, producing major flash floods in some areas. In terms of material losses, approximately 4000 houses, more than 3000 shops, and 1500 cars were damaged, besides other damage to infrastructures and public property. The damage as a whole was estimated at more than 21 million. Between 8000 and 10000 claims were received by the Spanish National Equalising Consortium of Insurance Companies (Consorcio de Compensación de Seguros). The meteorological features of this event have been analysed in detail by Barrera et al. (2007). 


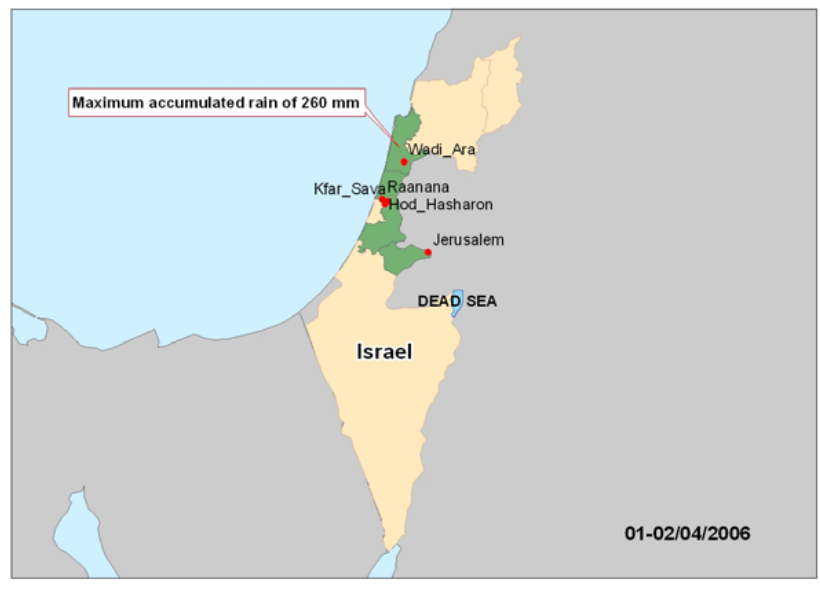

Fig. 6. Map of Israel with the affected areas in the event of 12 April 2006.

\section{(c) 12-14 September 2006, Spain and Italy}

Between 12 and 14 September 2006 some extraordinary flash floods were recorded in Catalonia (Spain) as a consequence of rainfalls above $100 \mathrm{~mm} / 24 \mathrm{~h}$, with maximum accumulated rainfall of $267 \mathrm{~mm}$ (Fig. 5c). It was a moderate convective event with the exception of the northern part, where convective precipitation exceeded $70 \%$ of the total rainfall. One person died while sleeping in a park. Besides damage to agriculture and urban areas, a traffic jam brought Barcelona city to a standstill, 40000 people were affected by railway cuts, Reus airport was closed and long delays were recorded at Barcelona International Airport. Ninety cars were carried away and part of the chemical park in Tarragona was flooded. As a consequence, all Catalan emergency Plans were activated. The CCS insurance company paid out 55993194 for damage produced by floods and landslides, and 3.15 million for damage caused by tornadoes. The event also affected the Western Liguria (Italy), with $165 \mathrm{~mm}$ in $8 \mathrm{~h}$ and flash floods in some small rivers. Damage was evaluated at 80 million due to flooded buildings, roads and railways, as well as cars and crop destruction (mainly vineyard and flowers). Although there were no casualties, one person was injured by lightning. A preliminary meteorological analysis of this event is shown in Barnolas et al. (2008).

\section{(d) 1-2 April 2006, Israel}

This event affected central and southern Israel, including Jerusalem and the Dead Sea region (Fig. 6), and was declared by the government as a natural disaster. Damage was caused to roads, sewage systems, electricity and water systems, agriculture and buildings, while five people died. The government and municipalities had to provide 44 million NIS (8.8 million) in assistance for recovering the Wadi Ara villages. Maximum rainfall of $260 \mathrm{~mm}$ was recorded in the

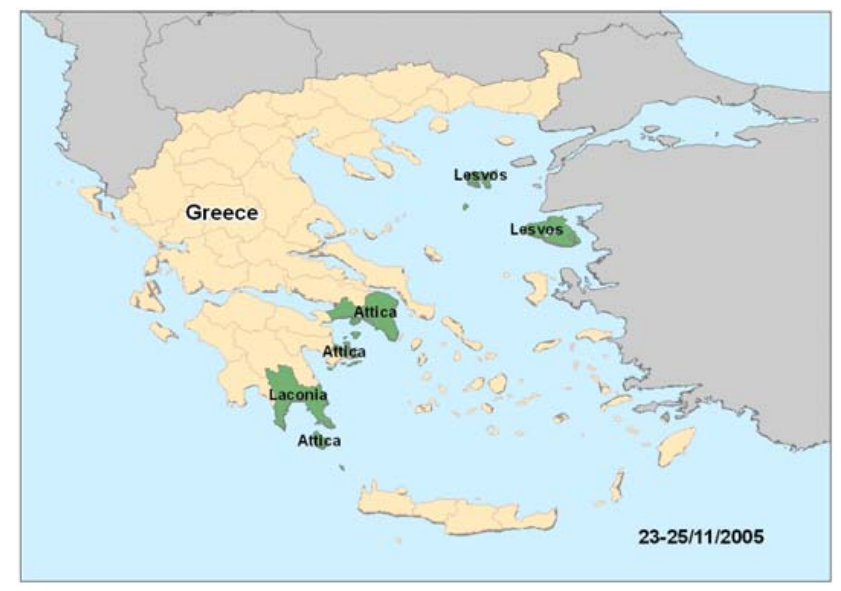

Fig. 7. Map of Greece with the affected areas in the event of 2325 November 2005.

Wadi Ara Region, with precipitation accumulations varying between $100-150 \mathrm{~mm}$ over an area of $17 \mathrm{~km}^{2}$ that produced a peak discharge of $122 \mathrm{~m}^{3} / \mathrm{s}$ in the Keini sub-basin, that has a total area of $10.5 \mathrm{~km}^{2}$ (Morin et al., 2007).

\section{(e) 23-25 November 2005, Greece}

This event affected the provinces of Attica, Laconia and Lesvos (Fig. 7). It produced extraordinary floods in the eastern Attica region causing damage to houses, stores and crops and one casualty in Laconia. Many areas of northern and central Greece, and Peloponnesus and the Aegean Islands recorded more than $100 \mathrm{~mm}$, with a maximum of $179 \mathrm{~mm}$ in $24 \mathrm{~h}$ at Athens Airport.

\section{(f) 6 November 2005, Cyprus}

Although it is not unusual for rainfall to exceed $200 \mathrm{~mm}$ in $24 \mathrm{~h}$ in the north-western Mediterranean countries, it is less frequent in the eastern part, and particularly in Greece and Cyprus. For the analysed period, the maximum daily accumulated rainfall in this last country has been of $110 \mathrm{~mm}$, recorded on 6 November 2005. The maximum hourly intensity was $27 \mathrm{~mm} / \mathrm{h}$ (Panagia Bridge) and damage was mainly related with land erosion. The analysis of the 6 November event, as well as the methodology used to analyse the other Cyprus FLASH cases is shown in Nicolaides et al. (2009).

\section{Conclusions}

The spatial distribution of the different kinds of floods is neither homogeneous in the region nor stationary over time, and shows a clear difference between the western Mediterranean and the eastern Mediterranean, with a major concentration in the former region. Flood events over the western part usually 
occur during autumn, while over the eastern part the major contribution is during the winter months. The highest flood frequency corresponds to Spain and Italy, but the material damage is particularly high in the latter country. Floods are less frequent in southern Mediterranean countries (northern Africa), but are usually catastrophic with a very high number of casualties. No significant trend has been found for the Mediterranean as a whole, or for a specific region. This result is in accordance with those obtained by Barriendos et al. (2003) and Llasat et al. (2005), working with series of more than 100 years. In the particular case of the countries involved in the FLASH project, an increased vulnerability has been found, mainly related with the population displacement towards the coastal regions, where flash floods are frequent. As a consequence, flash-floods disturb everyday life and cause minor damages almost every year.

This paper reflects the results obtained after intensive work on data integration between different databases, scientific works and proxy-data information (such as newspapers). However, we consider that it only shows preliminary results, due to the heterogeneity of the information furnished by the different countries. In some of them, additional floods not included in any database, paper or project consulted for this work may have been documented. Besides this, all flood events have been considered, without imposing any threshold. Future research will include new results generated within the framework of current projects, as well as new criteria to classify the events.

Acknowledgements. The authors acknowledge the following projects for the data supplied: MEDEX RINAMED, AMPHORE, SPHERE. This research was supported under the Sixth Framework Programme European Commission FLASH project (n.036852). Our thanks to M. Barnolas and L. López for their collaboration.

Edited by: A. Orphanou

Reviewed by: E. Ferrari and another anonymous referee

\section{References}

Barnolas, M. and Llasat, M. C.: A flood geodatabase and its climatological applications: the case of Catalonia for the last century, Nat. Hazards Earth Syst. Sci., 7, 271-281, 2007, http://www.nat-hazards-earth-syst-sci.net/7/271/2007/.

Barnolas, M., Atencia, A., Llasat, M. C., and Rigo, T.: Characterization of a Mediterranean flash flood event using rain gauges, radar, GIS and lightning data, Adv. Geosci., 17, 1-7, 2008, http://www.adv-geosci.net/17/1/2008/.

Barredo, J. I.: Major flood disasters in Europe: 1950-2005, Nat. Hazards, 42, 125-148, 2007.

Barrera, A., Llasat, M. C., and Barriendos, M.: Estimation of extreme flash flood evolution in Barcelona County from 1351 to 2005, Nat. Hazards Earth Syst. Sci., 6, 505-518, 2006, http://www.nat-hazards-earth-syst-sci.net/6/505/2006/.
Barrera, A., Altava-Ortiz, V., Llasat, M. C., and Barnolas, M.: Heavy rain prediction using deterministic and probabilistic models - the flash flood cases of 11-13 October 2005 in Catalonia (NE Spain), Adv. Geosci., 12, 121-126, 2007, http://www.adv-geosci.net/12/121/2007/.

Barriendos, M., Coeur, D., Lang, M., Llasat, M. C., Naulet, R., Lemaitre, F., and Barrera, A.: Stationarity analysis of historical flood series in France and Spain (14th-20th centuries), Nat. Hazards Earth Syst. Sci., 3, 583-592, 2003,

http://www.nat-hazards-earth-syst-sci.net/3/583/2003/.

Casas Planes, A., Benito, G., Díez Herrero, A., and Barriendos, M.: SPHERE-GIS: Implementation of an historical and palaeoflood geographical information system, in: Palaeofloods, Historical Floods and Climatic Variability: Applications in Flood Risk Assessment, edited by: Thorndycraft, V. R., Benito, G., Barriendos, M., and Llasat, M. C., Proceedings of the PHEFRA Workshop, Barcelona, 16-19 October 2002, 363-368, 2003.

CRED - Hoyois, P., Below, R., Scheuren, J.-M., and GuhaSapir, D.: Annual Disaster Statistical Review: Number and Trends 2006, Brussels, 2007.

ESPON (2000-2006): The Spatial Effects and Management of Natural and Technological Hazards in Europe, edited by: SchmidtThomé, P., 2006.

Forte, F., Pennetta, L., and Strobl, R. O.: Historic records and GIS applications for flood risk analysis in the Salento peninsula (southern Italy), Nat. Hazards Earth Syst. Sci., 5, 833-844, 2005, http://www.nat-hazards-earth-syst-sci.net/5/833/2005/.

Gaume, E., Bain, V., Bernardaza, P., Newinger, O., Barbuc, M., Bateman, A., Blaškovicová, L., Blöschl, G., Borga, M., Dumitrescu, A., Daliakopoulos, I., Garcia, J., Irimescu, A., Kohnova, S., Koutroulis, A., Marchi, L., Matreata, S., Medina, V., Preciso, E., Sempere-Torres, D., Stancalie, G., Szolgay, J., Tsanis, J., Velasco, D., Viglione, A.: A compilation of data on European flash floods, J. Hydrol., 367, 70-78, 2009.

Guzzetti, F., Cardinali, M., and Reichenbach, P.: The AVI Project: A bibliographical and archive inventory of landslides and floods in Italy, Environ. Manage., 18, 623-633, 1994.

Guzzetti, F. and Tonelli, G.: Information system on hydrological and geomorphological catastrophes in Italy (SICI): a tool for managing landslide and flood hazards, Nat. Hazards Earth Syst. Sci., 4, 213-232, 2004, http://www.nat-hazards-earth-syst-sci.net/4/213/2004/.

IPCC: Climate Change 2007, Impacts, Adaptation and Vulnerability, Cambridge Univ. Press, 986 pp., 2007.

Lagouvardos, K., Kotroni, V., Dobricic, S., Nickovic, S., and Kallos, G.: On the storm of 21-22 October 1994 over Greece: Observations and model results, J. Geophys. Res., 101(D21), 26217-26226, 1996.

Lastoria, B., Simonetti, M. R., Casaioli, M., Mariani, S., and Monacelli, G.: Socio-economic impacts of major floods in Italy from 1951 to 2003, Adv. Geosci., 7, 223-229, 2006, http://www.adv-geosci.net/7/223/2006/.

Legrand, P., Brugnot, G., and Baumont, G.: Rétour d'experience des inondations de septembre de 2002 dans les départaments du Gard, de l'Hérault, du Vaucluse, des Bouches de Rhône, de l'Ardèche et de la Drôme, Contribution du Groupe d'Appui et d'expertise scientifique, on CD-ROM, 2003. 
Llasat, M. C.: An objective classification of rainfall events on the basis of their convective features, Application to rainfall intensity in the north-east of Spain, Int. J. Climatol., 21, 1385-1400, 2001.

Llasat, M. C.: Chapter 18: Storms and floods, in :The Physical Geography of the Mediterranean basin, edited by: Woodward, J., Oxford University Press, 504-531 pp., 2009.

Llasat, M. C., Barriendos, M., Barrera, T., and Rigo, T.: Floods in Catalonia (NE Spain) since the 14th century, Climatological and meteorological aspects from historical documentary sources and old instrumental records, J. Hydrol., 313, 32-47, 2005.

Llasat, M. C., Llasat-Botija, M., and López, L.: A press database on natural risks and its application in the study of floods in Northeastern Spain, Nat. Hazards Earth Syst. Sci., 9, 2049-2061, 2009, http://www.nat-hazards-earth-syst-sci.net/9/2049/2009/.

Llasat, M. C., López, L., Barnolas, M., and Llasat-Botija, M.: Flash-floods in Catalonia: the social perception in a context of changing vulnerability, Adv. Geosci., 17, 63-70, 2008, http://www.adv-geosci.net/17/63/2008/.

Morin, E., Harats, N., Jacoby, Y., Arbel, S., Getker, M., Arazi, A., Grodek, T., Ziv, B., and Dayan, U.: Studying the extremes: hydrometeorological investigation of a flood-causing rainstorm over Israel, Adv. Geosci., 12, 107-114, 2007, http://www.adv-geosci.net/12/107/2007/.

Munich Re Group: World of Natural Hazards, on CD-ROM, Order number: 302-02650, Germany, 2004.
Naulet, R., Lang, M., Coeur, D., and Gigon, C.: Collaboration between historians and hydrologists on the Ardeche river (France), First step: Inventory of Historical Flood Information, Advances in Natural and Technological Hazards Research, Vol. 17 "The Use of Historical Data in Natural Hazard Assessments", edited by: Glade, T., Albini, P., and Frances, F., Kluwer Academic Publishers, Dordrecht, 113-129, 2001.

Nicolaides, K. A., Michaelides, S. C., Savvidou, K., Orphanou, A., Constantinides, P., Charalambous, M., and Michaelides, M.: Case studies of selected Project "Flash" events, Adv. Geosci., 17, 93-98, 2009, http://www.adv-geosci.net/17/93/2009/.

Petrucci, O. and Versace, P.: Conoscere il passato per prevedere il futuro, Dipartimento Protezione Civile Informa, 29, 25-26, 2000.

Petrucci, O. and Polemio, M.: The use of historical data for the characterisation of multiple damaging hydrogeological events, Nat. Hazards Earth Syst. Sci., 3, 17-30, 2003, http://www.nat-hazards-earth-syst-sci.net/3/17/2003/.

Rigo, T. and Llasat, M. C.: Radar analysis of the life cycle of Mesoscale Convective Systems during the 10 June 2000 event, Nat. Hazards Earth Syst. Sci., 5, 959-970, 2005, http://www.nat-hazards-earth-syst-sci.net/5/959/2005/.

Savvidou, K., Nicolaides, K. A., Michaelides, S. C., Orphanou, A., Charalambous, M., and Adamou, S.: A study of the flood events in Cyprus, Adv. Sci. Res., 2, 127-131, 2008.

Stanescu, V. A.: The extreme floods in Europe, An analysis of their occurrence and regionalization, unpublished note, personal communication, 2000. 